\title{
IF IT IS THE TOPIC OF THE RESEARCH OF THE INFORMAL ECONOMY
}

\author{
Ionel Bostan \\ Faculty of Law and Administrative Sciences, Stefan cel Mare University of Suceava \\ ionel_bostan@yahoo.com
}

\begin{abstract}
For many reasons, it can not be said that it is no longer necessary to investigate phenomena and processes related to the informal economy. In some of these we will also refer to this article. For example, issues related to fraud and tax evasion are of any interest. Also, black work, its motivations and its forms. Instead, it does not deal with tort / delict activities, including prostitution and prostitution, prohibited gambling, drug trafficking, counterfeiting or insurance fraud.
\end{abstract}

Key-words: Underground economy; the facets of tax evasion; clandestine work; the domestic economy and volunteering.

21 years ago I published the book Informal Economic Environments, published at the BIT Publishing House (lasi, RO), which addressed what we considered then to be the

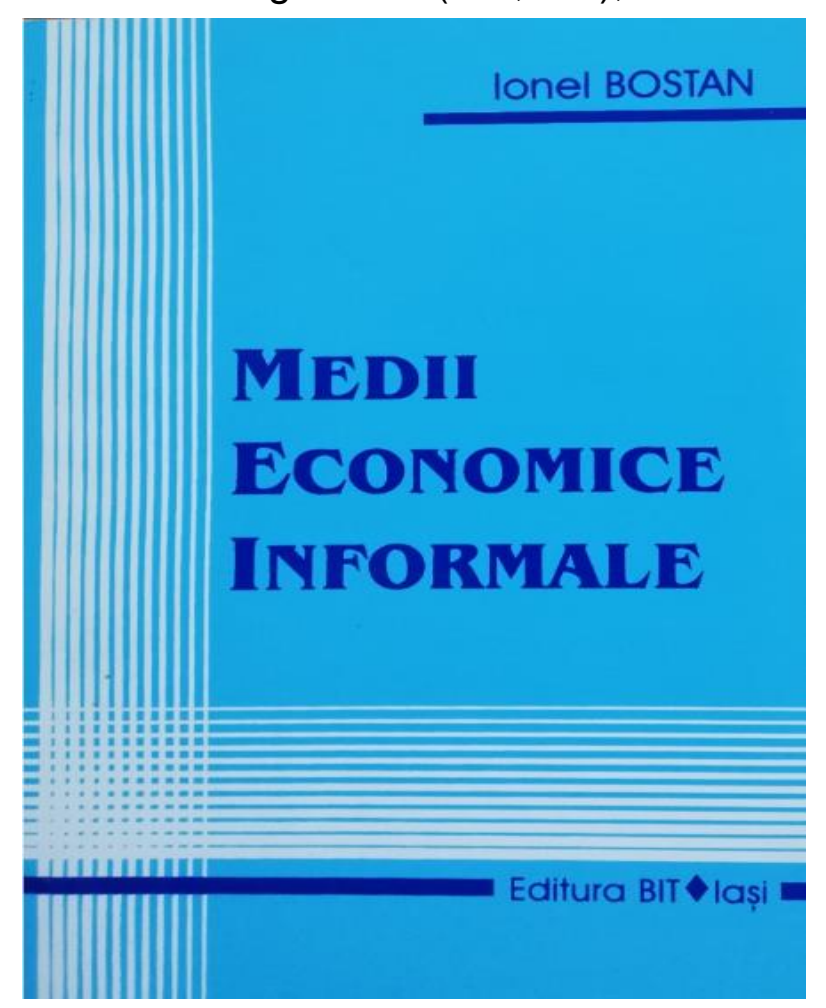
underground economy. At that moment it was appreciated that the approach was harsh, given that "recognized personalities in the economic or journalistic field have approached such problems only in a sequential manner" (V. Codreanu, in the Preface). The same precursor notes that "Approaching the mechanisms of the underground economy and understanding their functioning is not intended to ensure its removal (perhaps, at most, its limitation), but will certainly make it easier to obtain more realistic assessments and knowledge of several aspects of it". With the sources of documentation at that time, we dealt with issues such as the identification elements of the informal economy, an overview of it, the measurement issues and the magnitude (in Romania and worldwide). When I approached the Fraud and Tax Evasion, I made a presentation of it, while also presenting the existing motivations and the extent.

He found his place and the treatment of the Customs as a "gate of the country and, at the same time, of evasion", after which we stopped to fight tax evasion, governmental strategies in this matter and financial-fiscal control. 
Concerning Black Work, I presented her motivations and specific forms. There were no references to the Evaluation of the phenomenon and the Avalanche of the transition (from that time). Obviously, I also had to deal with the treatment of clandestine labor, the consequences of black work, but also aspects of Repression of the phenomenon. Finally, more pages were devoted to the Domestic Economy and volunteering, as some implications in the field.

Some time after the publication of the above-mentioned book, we had various research topics, some related to those presented here [1-4], others being different [4-29]. But the conclusion that needs to be made can only be that the research of the informal economy must not be abandoned, so that society has the tools needed to control the negative economic phenomena. Currently, Romania ranks second in the EU in terms of the size of the underground economy. Some data are alarming: "27.8\% of Romania's GDP is non-taxed, cash payments being directly proportional to the size of the underground economy." The same source shows that the share of cash is huge in Romania, with the monetary mass being 6 times higher than the European average [30].

That is why the proximity to research of the mechanisms of the underground economy and the understanding of their functioning are additional urgency for Romania.

\section{References}

[1]. Bostan, I. (2007). Investigaţii financiare: control extern-inspecţie fiscală-expertiză contabilă. laşi: Tipo Moldova.

[2]. Bostan, I. (2008). Drept financiar. laşi: Tehnopress.

[3]. Bostan, I.; Morariu, A.; Costea, I.M. (2006). Drept financiar public. Cluj: Dacia.

[4]. Bostan, I. (2016). Leveraging Sustainability as Budgetary resources through Financial Law Instruments. Annals "Constantin Brâncuşi" University/ Economy Series, 33-42.

[5]. Bostan, I.; Grosu, V. (2011). Contribution of balance scorecard model in efficiency of managerial control. Romanian Journal of Economic Forecasting 14 (3), 178-199.

[6]. Bostan, I.; Burciu, A.; Grosu, V. (2010). The consumerism and consumer protection policies in the European Community. Theoretical and Applied Economics no. 4, pp. 17-32.

[7]. Bostan, I. (2010). Drept bugetar european. Iaşi: Tipo Moldova.

[8]. Bostan, I. (2016). An analysis of the "bio" / "eco" products market, referring to the EU and Romania. CES Working Papers 1 (8), 33-44.

[9]. Tinică, G.; Bostan, I.; Grosu, V. (2013). Corelaţii privind creşterea economică şi evoluţia costurilor aferente maladiilor cronice. Revista Română de Bioetică 8 (3), 15-24.

[10]. Burciu, A.; Bostan, I.; Condrea, P.; Grosu, V. (2010). Financing the environmental policies in the communitarian space. Environ Eng Manag J, 9(9): 1179-1185.

[11]. Hlaciuc, E.; Morariu, A.; Burciu, A.; Bostan, I. (2012). Eficientizarea administraţiei publice locale prin aplicarea managementului modern al resurselor umane. Cluj-Napoca: Risoprint.

[12]. Mates, D.; Bostan, I.; Socoliuc, M.; Grosu, V. (2008). The Importance of The Accounting Information in The Process of Communication. Analele UEMR-ZEC.

[13]. Maxim, A.; Mihai, C.; Apostoaie, C.M.; Popescu, C.; Istrate, C.; Bostan, I. (2016). Implications and measurement of energy poverty across the European Union. Sustainability, 8 (5), 483, doi:10.3390/su8050483

[14]. Iatco, C.; Bostan, I.; Lazar, C.; Burciu, A. (2013). Reconsidering economic coal resources in drafting energy strategies. The case of Romania. Environ Eng Manag J, 12(10): 2025-2030.

[15]. Roman, T.; Bostan, I.; Manolică, A.; Mitrica, I. (2015). Profile of Green Consumers in Romania in Light of Sustainability Challenges and Opportunities. Sustainability 7 (6), 6394-6411. 
[16]. Popescu, C.C.; Bostan, I.; Robu, I.B.; Maxim, A.; Diaconu, L. (2016). An Analysis of the Determinants of Entrepreneurial Intentions among Students: A Romanian Case Study. Sustainability 8 (8), 771, doi:10.3390/su8080771

[17]. Bostan, I. (2005). Guidelines in the audit of Risk assessment. Comunicare susţinută cu ocazia Conferinţei, Probleme actuale ale situaţiei ale situaiei social-economice a Republicii Moldova, organizată de Facultatea de Ştiinţe Economice a Universităţii de Stat, Publication date: 2005/11/26, Vol.1, Pages 215, Publisher: USM Chisinau. Retrieved from: https://scholar.google.com/scholar?hl=en\&as_sdt=0,5\&cluster=14683141737133830369

[18]. Bostan, I.; Burciu, A.; Condrea, P. (2010). Trends of the communitarian cohesion policies and advertising for eco-investments. Environ Eng Manag J, 9(6):847-851.

[19]. Bostan, I.; Burciu, A.; Condrea, P.; Durac, G. (2009). Involvement of legal responsibility for severe acts of pollution and noncompliance. Environ Eng Manage J, Vol. 8, Issue: 3, Pages: 469-473.

[20]. Bostan, I.; Mates, D.; Grosu, V.; Socoliuc, M. (2008). Implications of fiscality over accounting in agriculture. Al 7-lea Simpozion Internaţional "Perspective Ale Agriculturii Mileniului III", Organizat de Universitatea de Ştiinţe Agricole si Medicină Veterinară Cluj-Napoca 2-4 Octombrie, 2008, in Bulletin of University of Agricultural Sciences Cluj-Napoca. Horticulture, Economics And Management Miscellaneous, 65(2):432.

[21]. Bostan, I. (2005). Company control implementation. Tehnologii moderne, calitate, restructurare (TMCR), Universitatea Tehnică a Moldovei, Chişinău, 19-21 Mai, pp. 305-308.

[22]. Costuleanu, C.; Bostan, I.; Horomnea, E.; Costuleanu, M.; Codreanu, C. (2011). Limitarea răspunderii civile în sfera auditării afacerilor, Economie teoretică și aplicată 18 (9), 562.

[23]. Tinică, G.; Bostan, I.; Grosu, V. (2008). The dynamics of public expenses in healthcare and demographic evolution in Italy and Romania. Revista Romana de Bioetica 6 (3), 56-63.

[24]. Roman, T.; Lazar, C.; Manolica, A.; Bostan, I. (2016). The current trends and opportunities in the industry of medical tourism. Journal of tourism - studies and research in tourism 22, 58-63.

[25]. Pohoață, I. Bostan, I.; Prelipcean, G.; Druguș, D.; Morariu, A.; Bunget, O. (2014). Equity, intra/inter-generation equalization and profit, in the context of the right to a healthy life and a clean environment. Rev. Rom. Bio. 12 (2), 58-69.

[26]. Bostan, I.; Onofrei, M. (2012). The economic analysis of the evolution of Romanian ferrous metallurgy. Metalurgija 51 (4), 548-550.

[27]. Morariu, A.; Bostan, I. (2012). Trends in personnel and productivity associated with the steel industry in the Romanian economy. Metalurgija 51 (4), 551-554.

[28]. Bostan, I. (2012). The balanced scorecard (BSC) implications on the increase of public companies performance. African Journal of Business Management 6 (22), 6465.

[29]. Bostan, I.; Costuleanu, C.; Horomnea, E.; Costuleanu, M. (2011). Morality, ethics and true image in business accounting. Theoretical and Applied Economics 6 (6), 47.

[30]. Vladimirescu, C. (2018). Despre economia subterană, https://www.wallstreet.ro/articol/Finante-Banci/219007/romania-locul-2-de-la-coada-clasamentului-ue-laeconomie-subterana.html 